\title{
ACRL's 2021 Awards Program Honoring outstanding achievements in the academic and research library community
}

E very year, ACRL celebrates the opportunity to honor the outstanding achievements of the academic and research library community. These inspiring innovators have continued to demonstrate the notable impact librarianship has in the academic landscape.

Made possible by generous corporate support, the annual presentation of our prestigious awards, grants, and fellowships to these deserving individuals and institutions enables ACRL to honor the very best in academic librarianship. This year, ACRL once again seeks to celebrate and recognize the accomplishments of our peers.

Members are an integral part of ACRL's successful awards program. Please consider acknowledging those who have influenced your thinking, your practice, and your growth as an academic or research library worker. We urge you to nominate colleagues whose work you admire, and whose contributions merit recognition by the profession. Your nominations will ensure that the pool of candidates for each award remains both competitive and distinguished.

Complete information about the ACRL awards program is available in the Awards \& Scholarships section of the ACRL website at www.acrl.org. December 4, 2020, is the deadline for most of the awards to be presented in 2021. A brief description of each award is listed below. We welcome your nominations and look forward to celebrating achievements in our community in 2021.

\section{Achievement and Distinguished Service Awards}

- Excellence in Academic Libraries Award (sponsored by GOBI Library Solutions from EBSCO): $\$ 3,000$ for one library in each of three categories (college, community college, and university) recognizing academic libraries that are outstanding in furthering the educational missions of their institutions.

- Academic/Research Librarian of the Year Award (sponsored by GOBI Library Solutions from EBSCO): \$5,000 award recognizing an outstanding member of the academic or research library profession.

- Hugh C. Atkinson Memorial Award (sponsored by ACRL and Core: Leadership, Infrastructure, Futures): Cash award recognizing outstanding achievements (including risk-taking) in the areas of library automation, management, or development and research.

- Community College Learning Resources Leadership/Library Achievement Awards (sponsored by EBSCO Information Services): $\$ 750$ for each of

Chase Ollis is ACRL professional development and outreach specialist, email: collis@ala.org

(C) 2020 Chase Ollis 


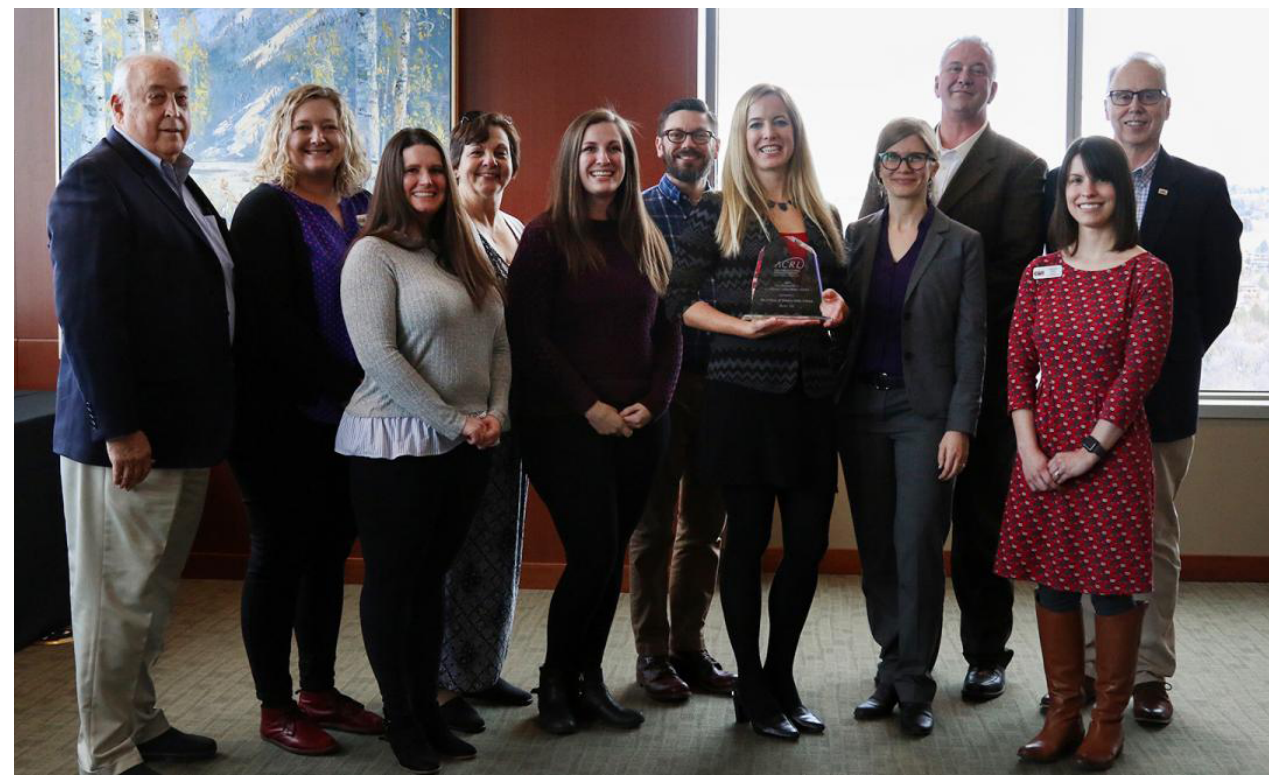

College of Western Idaho Library staff receiving Excellence in Academic Libraries Award.

two awards recognizing outstanding achievement in library programs or leadership.

- College Libraries Section Innovation in College Librarianship Award (sponsored by SCELC): $\$ 1,000$ award recognizing librarians who demonstrate a capacity for innovation in working with or serving undergraduates or instructors in the areas of programs, services, and operations or creating innovations for library colleagues that facilitate their ability to better serve the library's community.

- Distinguished Education and Behavioral Sciences Librarian Award (sponsored by the American Psychological Association): \$2,500 award honoring outstanding contributions to education and behavioral sciences librarianship through accomplishments and service to the profession.

- Instruction Section Innovation Award (sponsored by EBSCO Information Services): \$3,000 award recognizing librarians who have implemented innovative approaches to information literacy at their respective institutions or in their communities.
- Miriam Dudley Instruction Librarian Award (sponsored by the ACRL Instruction Section): \$1,000 award recognizing an individual librarian for significant contributions to the advancement of instruction in a college or research library environment.

- Politics, Policy, and International Relations Section Marta Lange/ SAGE-CQ Press Award (sponsored by SAGE-CQ Press): $\$ 1,000$ award recognizing a librarian who has made distinguished contributions to bibliography and information service in law or political science.

- Routledge Distance Learning Librarianship Conference Sponsorship Award (sponsored by Routledge/ Taylor \& Francis Group): \$1,200 conference sponsorship award to honor any individual ACRL member working in the field of, or contributing to the success of, distance learning librarianship or related library service in higher education.

- University Libraries Section Outstanding Professional Development Award (sponsored by Library Juice Academy): \$1,000 award recognizing 
librarians, archivists, or curators whose contributions to providing professional development opportunities for librarians have been especially noteworthy or influential.

- Women \& Gender Studies Section Awards for Career and Significant Achievement (sponsored by Duke University Press): $\$ 750$ for each of two awards recognizing career achievement and outstanding contributions in women and gender studies librarianship through accomplishments and service to the profession.

\section{Publications}

- Katharine Kyes Leab and Daniel J. Leab Exhibition Catalogue Awards (sponsored by Katharine Kyes Leab and Daniel J. Leab, American Book Prices Current): Recognizes outstanding catalogs published by American or Canadian institutions in conjunction with library exhibitions. Deadline: October 15, 2020.

- Ilene F. Rockman Instruction Publication of the Year Award (sponsored by Carrick Enterprises): $\$ 1,000$ award recognizing an outstanding publication related to instruction in a library environment published in the last two years.

- Science and Technology Section Oberly Award for Bibliography in the Agricultural or Natural Sciences: Cash award given in odd-numbered years recognizing the best English-language bibliography in the field of agriculture or a related science.

For more information about the ACRL Awards Program, visit the Awards \& Scholarships section of our website at www.acrl.org or contact ACRL Professional Development and Outreach Specialist Chase Ollis at collis@ala.org. „2

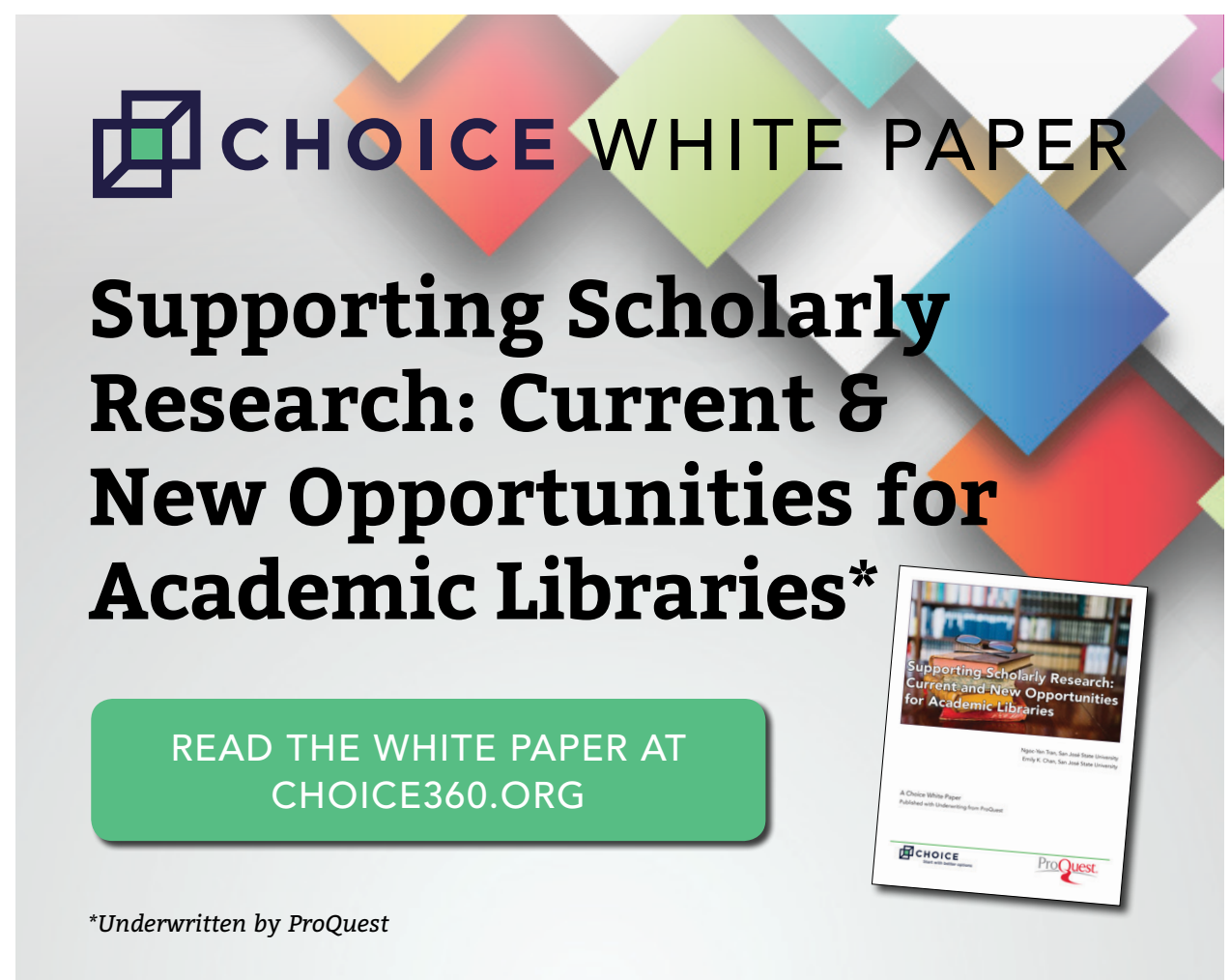

